\title{
Author's Response: Some Thoughts on War Prisons, the Law of Nations, and Historical Comparisons
}

\section{Renaud Morieux}

Faculty of History, University of Cambridge, Cambridge, UK

Email: rm656@cam.ac.uk

The society of prisoners: Anglo-French wars and incarceration in the eighteenth century. By Renaud Morieux. Oxford: Oxford University Press, 2019. Pp. viii + 421. ISBN 9780198723585.

It is an honour and a pleasure to be able to converse with four such generous and thoughtful readers. I am relieved that Guillaume Calafat agrees with me, rather than with Julien Duvivier, that prisoners of war are, as the saying goes, good to think with! I also appreciate their suggestions for future research avenues, which I think open up a number of exciting possibilities. In order to give those readers who have not read the book a sense of what they will get out of it, my response will focus on issues on chronology, historiography, and methodology.

One of the main issues raised by all four panellists is that of change over time. Margaret Hunt is right to point out that I try in this book to avoid a teleology linking the eighteenth century and the twentieth. The problem with such teleological accounts is not just that, as she indicates, the eighteenth century is interesting to study for its own sake. I do certainly emphasize the multiple contradictions which characterized the laws of war and the law of nations in the eighteenth century, especially at sea. This does not mean, however, that I am not interested in long-term continuities and comparisons, and my hope is that the book can also help us think critically about our present. For instance, the meshing of private contractors, public and civilian actors in the prisoner-of-war regime is not just a characteristic of the eighteenth century: think about the role of private corporations in the detaining of war combatants in Afghanistan, Iraq, or Guantanamo. Wars have always been more than state

\footnotetext{
(C) The Author(s), 2021. Published by Cambridge University Press. This is an Open Access article, distributed under the terms of the Creative Commons Attribution-NonCommercial-NoDerivatives licence (http://creativecommons.org/licenses/by-nc-nd/4.0), which permits non-commercial re-use, distribution, and reproduction in any medium, provided that no alterations are made and the original article is properly cited. The written permission of Cambridge University Press must be obtained prior to any commercial use and/or adaptation of the article.
} 
affairs, and this leads us to question well-established narratives about the end of 'private' wars after the middle ages and the rise of the modern state.

This chronological reframing also has implications for how we write the history of international law. Calafat asks whether I want to get rid of the concept of international law altogether. I do not have a problem with the use of the term for this period: after all, Jeremy Bentham used it in $1780 .{ }^{1}$ But I do want to move away from the obsession with the so-called 'fathers' of modern international law, legal writers like Vattel - whose ideas about the 'just' treatment of prisoners of war were much more ambiguous than is often said. Instead, I want to draw attention to the many ways in which the law operated in this period. One must pay close attention to the plurality of normative systems. At certain times, for instance during the Revolutionary and Napoleonic Wars, moral, 'humanitarian', and legal norms could clash with another imperative, that of winning wars. This tension is constitutive of the figure of the prisoner of war, this enemy protected by the state. Like the unlawful enemy combatants of Guantanamo, Napoleon was brought to St Helena as the prisoner of a perpetual war, a hostis humani generis who could never be freed because he was at war against civilization and humanity. Crucially, however, he was portrayed by British jurists and politicians as an exception within the law of nations.

Inspired in particular by the work of Lauren Benton, with its attention to the legal cultures of multiple actors, the book offers what we might call a concrete history of legal knowledge. Starting with the 'indigenous' categories historical actors mobilized in concrete situations can be very fruitful. There was no agreement as to whether women, black sailors, or religious minorities were prisoners of war, which left considerable room for interpretation to actors on the ground, such as ship captains, state bureaucrats, guards, or prisoners. My reflection on legal categories, as Guillaume Calafat, Margaret Hunt, and Rachel Weil all point out, is pivotal to my argument. Despite the emergence of new efforts to codify the law of nations during this period, distinctions between prisoner of war, hostage, criminal, and slave still depended on context. These various conditions can be compared laterally and synchronically rather than genealogically: I borrowed from studies of slavery and captivity in the Atlantic and the Mediterranean the idea that forms of war imprisonment must be placed on a spectrum.

I characterized the approach I took in my previous book as a form of 'transnational history from below', and I agree with Hunt that this applies just as well to The society of prisoners. ${ }^{2}$ As Calafat notes, there are other connections between the two projects. They share the idea that, even though the imprisonment of the enemy signals the extension across the globe of Franco-British rivalry during this period, the social forms that incarceration took illustrate the persistence of non-conflictual relations within war itself. Hunt makes an

\footnotetext{
${ }^{1}$ David Armitage, 'Parliament and international law in the eighteenth century', in Julian Hoppit, ed., Parliaments, nations and identities in Britain, 1660-1850 (Manchester, 2003), pp. 169-86.

${ }^{2}$ The Channel: England, France and the construction of a maritime border in the eighteenth century (Cambridge, 2016), p. 14.
} 
important point about the disproportionate attention I pay to the societies of prisoners, rather than the people they left behind during their incarceration. Before answering this, it is perhaps necessary to explain that the title of my book is a reference to Gresham Sykes's classic sociological study, The society of captives. ${ }^{3}$ While Sykes was above all interested in prisoners and their interactions with guards, I take the society of prisoners to mean both the prison as society and the prison in society. My book analyses the consequences of the presence of prisoners on society at large in the host country. By entering the prison, I also study the rich social interactions which took place there. Separating any prison from 'outside' society is problematic because, as McGowen notes, carceral institutions were porous. I show the imbrication and interdependence of prisons with local societies, a feature also observed by sociologists of contemporary prisons, such as Philippe Combessie and Laura Piacentini. ${ }^{4}$ Even in the most 'modern' war prisons of the early nineteenth century, institutions like Dartmoor modelled on Bentham's panopticon, there existed prison markets where prisoners bought goods from local populations and sold objects to them. Besides the prison and the host society, the third polarity, in the configuration I just outlined, is the home society of the prisoners.

The prisoners' families are not completely absent from my book, but it is fair to say that they do not occupy as much space as they could. More broadly, I wanted to write about gender relations, but that chapter never survived the draft stage. Hunt is absolutely right that the prisoners' wives did not remain outside the game of international relations: they petitioned local and state authorities to obtain the release of their husbands, and demonstrated outside the doors of naval administrators when transport ships returned empty. On average, a French privateer captain stayed three years and seven months in captivity in Britain during the Seven Years' War. How did these men's families cope with their absence? Letters exchanged between prisoners and their folk show how resilient family ties could be even in times of war. This leads us to a related question: how much does this book on prisoners of war tell us about periods of peace? One way of addressing this problem would be to follow prisoners' trajectories after the wars, including those of the many who never returned home. Another is to look at how their wives, children, and elderly relatives survived without them, by relying on state pensions, remarrying, or moving elsewhere. I am currently working on the impact of war on women and the family, and I hope this work will address some of the issues Hunt raises.

Since this is a transnational history, a word about scales of analysis is warranted. Prisoners of war were captured and detained almost everywhere, from Quebec to Madras, from Edinburgh to Minorca. I had to make choices, and I decided to favour the Atlantic over the Indian Ocean or the Mediterranean. The Caribbean basin was an ideal unit of observation, due to the number of

\footnotetext{
${ }^{3}$ Gresham Sykes, The society of captives: a study of a maximum security prison (Princeton, NJ, 1958).

${ }^{4}$ Philippe Combessie, Prisons des villes et des campagnes: étude d'écologie sociale (Paris, 1996); Laura Piacentini, Surviving Russian prisons: punishment, economics and politics in transition (Cullompton, 2004).
} 
prisoners taken there, the entangled sovereignties of European powers, and the systemic forced mobility that tied the region together. The region's sheer geographical distance from Europe and the nature of its connections with North America also allowed me to study more closely the capacity of central empires to govern colonial spaces. On a different scale, an island can, in certain conditions, be deemed to be a society of prisoners, and this is one of the ideas that I put forward in the epilogue: between 1815 and 1821, St Helena became an island-prison, whose ecosystem revolved around Napoleon and his retinue. In this sense, I am very pleased with Calafat's insightful suggestions on the Mediterranean as another society of prisoners. One might add lazaretti to the list of institutions that should be considered in the same bracket. After all, for his An account of the principal lazarettos in Europe (1st edn 1789), the prison reformer John Howard went to Marseilles, Genoa, Salonica, Malta, and Corfu, building on his earlier writings on prisons and prisoners of war.

Howard is the obvious link between prisoners of war and prison reform, which both McGowen and Weil address. In tying prisoners of war to discussions about other forms of imprisonment, I was precisely trying to encourage us to consider the possibility that the British case was neither unique nor incomparable. Prison reformers themselves were engaged in international discussions, either because they actively wanted, like John Howard, to emulate foreign models, or because foreign prisoners were dumped on their shiny new houses of correction, as was the case of G. O. Paul. In the last three decades, historians have argued that we should not think in terms of one single prison reform, because multiple types of imprisonment continued to co-exist in Britain well into the eighteenth century, and local and regional variations predominated. ${ }^{5}$ There were also different conceptions of what 'reforming' prisoners might mean. A complex patchwork, therefore, has replaced the reassuring canvas that was still in favour until the 1980s. Picking up on Rachel Weil's comment, bringing prisoners of war into the picture seems to make things even messier. The explanations she suggests for the rejection of prisoners of war by prison reformers are compelling. Her reading of John Howard's ambiguities on the subject applies to other reformers as well: why should the country gentry, and not the state, have to pay for the sustenance of the nation's enemies? Who was more dangerous, prisoners of war or felons? Why should enemies be protected in wartime anyway? Different people had different views on this, because the detention of prisoners of war served multiple and contradictory aims. In turn, the experience of prisoners of war varied considerably, depending on the type of prisons they were detained in, and whether their custodians felt the necessity to abide by the law of nations or not. While they were not 'guilty', many prisoners of war were made to feel like criminals and punished as such. In France, as shown by the violence towards prisoners of

\footnotetext{
${ }^{5}$ Joanna Innes opened the door to this rethinking: 'The King's Bench prison in the later eighteenth century: law, authority and order in a London debtor's prison' (1980), repr. in Inferior politics: social problems and social politics in eighteenth-century Britain (Oxford, 2009), pp. 227-78; 'Prisons for the poor: English bridewells, 1555-1800', in Francis Snyder and Douglas Hay, eds., Labour, law, and crime: an historical perspective (London, 1987), pp. 42-122.
} 
war during the French Wars, the notion that they were not like other enemies was tested like never before.

In answer to McGowen's final point, the political and economic changes at the end of the eighteenth century, which had led to new forms of imprisonment being imagined, certainly affected the prisoner-of-war system as well, and the two were related. In the late eighteenth and early nineteenth centuries, there were fears in Britain that prisoners of war furthered domestic radicalism: there were for instance allegations of their role in the 1797 naval mutinies, and it was believed the presence of these thousands of foreigners on home soil encouraged immorality. Hence the perceived need to further insulate prisoners of war from the wider population. While the purpose of war prisons was never to 'reform', during the Napoleonic Wars missionaries were for the first time sent there to convert prisoners of war. The building of major war prisons in Britain illustrates a move towards the specialization of detention for these inmates; at the same time, these new purpose-built war prisons were from the outset imagined as adaptable and 'recyclable'. Dartmoor, which was built by prisoners of war, was destined to be turned after the war into a prison for convicts on their way to New South Wales. One must think, then, of prisons as multi-layered spaces.

There are clear similarities and connections between the carceral societies built up around prisoners of war and other modes of detention. But I want to stress, in closing, the specificities of the prisoner of war's experiences. These were due, in part, to 'national' and linguistic differences. These people can usefully, I contend, be cast as mediators between colliding societies. As Hunt remarks, this function includes the circulation of information and rumour, which leaked through prison walls. Sociologists have underlined the importance of the accommodations that are part of everyday prison life. These types of compromises were harder to negotiate when captors and captives did not share the same language and norms. Wars created new kinds of social relations, and destroyed others. Fraternization could occur across national and social boundaries, facilitating all kinds of traffics and escapes, but misunderstandings could easily flare up as well. Because many prisoners, such as the prisoners on parole, had relatively easy access to the outside world, some felt more closely linked to their host country than to the one they had left behind, switching allegiances or marrying local women. This brings us back, in the end, to the question of categories. Michael Walzer talks about 'the limbo of statelessness' to denote the strangeness of the prisoner of war experience. $^{6}$ By becoming captives of another state, these people were transient beings, stuck between two countries, never belonging fully to either.

\footnotetext{
${ }^{6}$ Michael Walzer, 'Prisoners of war: does the fight continue after the battle?', American Political Science Review, 63 (1969), p. 777.
}

Cite this article: Morieux R (2022). Author's Response: Some Thoughts on War Prisons, the Law of Nations, and Historical Comparisons. The Historical Journal 65, 540-544. https://doi.org/10.1017/ S0018246X2100039X 